\title{
Effect of Different Levels of NPK and Vermicompost on Physico-Chemical Properties of Soil, Growth and Yield of Okra [Abelmoschus esculentus L.] var. Rohini
}

\author{
Reena Lakra*, Narendra Swaroop and Tarence Thomas
}

\author{
Department of Soil Science and Agricultural Chemistry, Sam Higginbottom University of \\ Agriculture, Technology and Sciences (Deemed-to-be-University), \\ Allahabad, 211007 U.P., India \\ *Corresponding author
}

\section{A B S T R A C T}

The field experiment was carried out at soil science research farm of Sam Higginbottom University of Agriculture, Technology and Sciences Allahabad, during Rabi season 201617. The design applied was $3 \times 3$ factorial randomized block design having three factors with

Keywords

Yield attributes, Okra NPK and Vermicompost Physico-chemical properties content, etc.

Article Info

\section{Accepted:}

17 June 2017 Available Online: 10 July 2017 three levels of N,P, K @ 0,50, and $100 \%$ ha $^{-1}$, three levels of vermicompost @ 0, 50 and $100 \% \mathrm{ha}^{-1}$ respectively. The result obtained with treatment $\mathrm{T}_{5}$-[NPK@ $50 \%+$ Vermicompost@100\%] that showed the highest yield regarding, gave the best results with respect to plant height $115.69 \mathrm{~cm}$, number of leaves per plant 49.33, Number of branch 48.50, Number of Fruit per plant 20.71, it gave highest yield, $199.21 \mathrm{q} \mathrm{ha}^{-1}$. The maximum cost benefit ratio was recorded 1: 8.55and net profit. Rs. 37,154.6 ha in $^{-1}$ treatment combination $\mathrm{T}_{5}-\mathrm{L}_{1} \mathrm{~V}_{2}$ [ @ $50 \% \mathrm{~N} \mathrm{P} \mathrm{K} \mathrm{ha}{ }^{-1}+100 \%$ Vermicompost ha ${ }^{-1}$ ] combined use of $\mathrm{N}, \mathrm{P}$ and $\mathrm{K}$ resulted in significant increase on enrichment of soil fertility status. Vermicompost in combination resulted in a slight increase in $\mathrm{pH} 7.40, \mathrm{EC} 0.52 \mathrm{dSm}^{-1}$. In post soil of $\mathrm{N}, \mathrm{P}$, and $\mathrm{K}$ fertilizers observations were resulted in significant increase in OC $0.84 \%$, particle density $2.73 \mathrm{M} \mathrm{gm}^{-3}$, bulk density $1.46 \mathrm{M} \mathrm{gm}^{-3}$, pore space $53.06 \%$ and

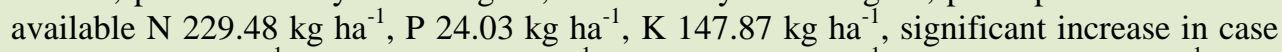
of nitrogen $\left(\mathrm{kg} \mathrm{ha}^{-1}\right)$, phosphorus $\left(\mathrm{kg} \mathrm{ha}^{-1}\right)$, potassium $\left(\mathrm{kg} \mathrm{ha}^{-1}\right)$, vermicompost $\left(\mathrm{t} \mathrm{ha}^{-1}\right)$ was found to be significant among other treatments in okra cultivation and soil quality improvement. It was also revealed that the application of NPK with Vermicompost were excellent source for fertilization than fertilizers. The treatment $\left(\mathrm{T}_{5}\right)$ also showed greater benefit cost ratio followed by other treatments.

\section{Introduction}

Okra is one of the most important vegetable crop grown in tropical and sub-tropical region and is said to be native of South Africa and Asia. In India, it is cultivated almost in all states throughout the year and consumed by bulk of the people. Major okra growing states in India are Uttar Pradesh, Bihar and Orissa. The total area under okra crop in India is about 533'000 ha with production of
6346'000 metric tonnes with productivity 11.90 metric tonnes. In Maharashtra it is grown on an area about 23,000 ha with production of $242^{\prime} 000$ metric tonnes with productivity 10.500 metric tonnes in year 2013-14 (Anonymous, 2014).

Bhendi being a short duration crop, its growth, yield and quality are largely 
influenced by the application of fertilizers (Somkumar et al., 1997).

Okra is popular and favorable vegetable, grown for tender fruits and fresh market consumption. It is one of the most nutritious vegetables which contains on an average 36 calories energy, $2.4 \mathrm{~g}$ protein, 89 per cent moisture, $0.3 \mathrm{~g}$ fat, $7.6 \mathrm{~g}$ carbohydrates, 92 $\mathrm{mg} \mathrm{Ca}, 51 \mathrm{mg} \mathrm{P}, 1.5 \mathrm{mg} \mathrm{Fe}, 3 \mathrm{mg} \mathrm{Na}$ and 103 $\mathrm{mg} \mathrm{K}$ per $100 \mathrm{~g}$ of fresh fruits (Bose et al., 1985).

Fertilizers and organic manures play an important role in increasing production, improving quality of vegetables and sustaining soil fertility. Organic manures contain all nutrients which are required for healthy growth of crop and help to improve physical, chemical and biological properties of soil (Halkatti et al., 1997).

Ever increasing cost of energy would be an important constraint for increased use of chemical fertilizers in crop production, use of organic manures to meet the requirement of crop would be an inevitable practice in years to come for sustainable agriculture (Vennila and Jayanthi, 2008).

Nitrogen, phosphorus and potassium are among the common major nutrients, which are essential for the growth and development of all plant species. Nitrogen is the important part of plant parts such as chlorophyll, amino acid, proteins and pigments. Nitrogen makes leafy vegetables and fodder more succulent. It also increases the protein content of food and feed.Therefore proper attention must be given to these nutrients while planning a project on plant nutrition (Khalil, 2006).

Phosphorus is a key element in the formation of high energy compounds, such as AMP, ADP and ATP, which play essential role in photosynthesis and respiration. It is a vital component of nucleic acids and phospholipids. Plants take up phosphorus in the inorganic form, mainly as the orthophosphate H2Po4 ion. Phosphorus supports early phase of crop development, synchronizes the germination process and leading to enhance the final yield, especially in P deficient soil (Arif et al., 2015).

It increases crop resistance to diseases. In contrast to $\mathrm{N}$, deficiency symptoms of $\mathrm{P}$ most often, occur in seedlings and young plants. Since $\mathrm{P}$ is mobile within the plant, symptoms appear on the lower leaves/parts of the plants (Khalil, 2006).

Vegetable seed production is unique from most agronomic crops as they must develop sufficient vegetative growth prior to cool temperature exposure in order that vernalization may successfully induce flower formation in the following season such as that in Okra.

Its seed production is affected by climatic factors and various agronomic practices including fertilizer application and planting density (Asgedom and Becker, 2001).

Among macronutrients, Phosphorus $(\mathrm{P})$ is an essential macronutrient that can limit plant growth if not provided in sufficient quantities by the soil or external sources.

For soils low in available $\mathrm{P}$, the nutrient must be applied in either organic or inorganic $\mathrm{P}$ sources to obtain optimal crop yield. However, excessive use of applied P sources can cause eutrophication in water bodies from surface runoff of sediments carrying $\mathrm{P}$ or leaching of $\mathrm{P}$ in sandy soils (Chien et al., 2011).

Many researchers reported the effect of phosphorus application on green pod yield of okra, which also improves root growth, 
hastens seed maturity and increases fruit yield especially when applied in combination with nitrogen (Sadat, 2000).

\section{Materials and Methods}

A field Experiment was conducted on research farm of department of Soil Science, Allahabad School of Agriculture, Sam Higginbottom University of Agriculture, Technology and Sciences Allahabad, (U.P.) India. The soil of experimental area falls in order Inceptisol and the experimental field is alluvial in nature.

The design applied for statistical analysis was carried out with 3 factorial randomized block design having three factors with three levels of NPK@0,50, and 100\% ha ${ }^{-1}$, three levels of Vermicompost@0, 50 and 100\% ha ${ }^{-1}$ respectively. Treatments were $\mathrm{T}_{0-}\left(\mathrm{L}_{0} \mathrm{~V}_{0}\right) @ 0$ $\%$ NPK ha ${ }^{-1}+0 \%$ Vermicompost ha ${ }^{-1}, \mathrm{~T}_{1}$ $\left(\mathrm{L}_{0} \mathrm{~V}_{1}\right) @ 0 \%$ NPK ha ${ }^{-1}+50 \%$ Vermicompost $\mathrm{ha}^{-1}, \mathrm{~T}_{2}-\left(\mathrm{L}_{0} \mathrm{~V}_{2}\right) @ 0 \% \mathrm{NPK} \mathrm{ha}^{-1}+100 \%$ Vermicompost ha ${ }^{-1}, \mathrm{~T}_{3}-\left(\mathrm{L}_{1} \mathrm{~V}_{0}\right) @ 50 \%$ NPK $\mathrm{ha}^{-1}+0 \%$ Vermicompost ha ${ }^{-1}, \mathrm{~T}_{4^{-}}\left(\mathrm{L}_{1} \mathrm{~V}_{1}\right) @$ $50 \%$ NPK ha ${ }^{-1}+50 \%$ Vermicompost ha ${ }^{-1}, \mathrm{~T}_{5^{-}}$ $\left(\begin{array}{ll}\mathrm{L}_{1} & \mathrm{~V}_{2}\end{array}\right) @ 50 \%$ NPK ha ${ }^{-1}+100 \%$ Vermicompost ha ${ }^{-1}, \mathrm{~T}_{6}-\left(\mathrm{L}_{2} \mathrm{~V}_{0}\right) @ 100 \%$ NPK ha ${ }^{-1}+0 \%$ Vermicompost ha ${ }^{-1}, \mathrm{~T}_{7}-\left(\mathrm{L}_{2}\right.$ $\mathrm{V}_{1}$ ) @ 100\% NPK ha ${ }^{-1}+50 \%$ Vermicompost $\mathrm{ha}^{-1}, \mathrm{~T}_{8}-\left(\mathrm{L}_{2} \mathrm{~V}_{2}\right) @ 100 \%$ NPK ha ${ }^{-1}+100 \%$ Vermicompost ha ${ }^{-1}$ having the treatments was replicated thrice.

The source of inorganic nutrients sources as Urea, SSP, MOP, and organic nutrients sources as Vermicompost respectively. Basal dose of fertilizer was applied in respective plots according to treatment allocation unifurrows opened by about $5 \mathrm{~cm}$. depth before sowing seeds in soil at the same time sowing of seeds was shown on well prepared beds in shallow furrows, at the depth of $5 \mathrm{~cm}$, row to row distance was maintained at $30 \mathrm{~cm}$ and plant to plant distance was $45 \mathrm{~cm}$, during the course of experiment, observations were recorded as mean values of the data.

\section{Results and Discussion}

\section{Plant height (cm)}

At 30 DAS, the maximum plant highest 25.85 $\mathrm{cm}$ in $\mathrm{T}_{5}$-[NPK@50\%+Vermicompost @ $100 \%]$, followed by $\mathrm{T}_{3}-[\mathrm{NPK} @ 50 \%+$ Vermicompost 0\%] was $24.53 \mathrm{~cm}$ and minimum plant height was observed in $\mathrm{T}_{0}$ (control) that is $21.52 \mathrm{~cm}$.

At $60 \mathrm{DAS}$, the maximum $90.74 \mathrm{~cm}$ in $\mathrm{T}_{5^{-}}$ [NPK@50\% + Vermicompost@100\%], followed by $\mathrm{T}_{3}$-[NPK@ 50\% + Vermicompost @0\%] was $88.23 \mathrm{~cm}$ and minimum plant height was observed in $\mathrm{T}_{0}$ (control) that is $81.40 \mathrm{~cm}$.

At 90 DAS the maximum $115.69 \mathrm{~cm}$ in $\mathrm{T}_{5^{-}}$ [NPK@ 50\% RDF + Vermicompost@ 100\%], followed by $\mathrm{T}_{8}$-[NPK@100\% + Vermicompost@50\%] the plant height was $113.53 \mathrm{~cm}$ and minimum plant height was observed in $\mathrm{T}_{0}$ (control) that is $105.71 \mathrm{~cm}$ (Mahapatra et al., 2013).

\section{Number of leaves}

At 30 DAS, the maximum number of leaves 13.33 in $\mathrm{T}_{5}$-[NPK@50\% + Vermicompost@100], followed by $\mathrm{T}_{8^{-}}$ [NPK@100\%+Vermicompost@100\%] the number of leaves was 12.41 and minimum number of leaves was observed in $\mathrm{T}_{0}$ (control) that is 9.06 .

At 60 DAS, the maximum 43.13 in $\mathrm{T}_{5}$-[NPK @50\% + Vermicompost@100\%], followed by $\mathrm{T}_{7-}$ [NPK@100\% + Vermicompost@ $50 \%$ ] the number of leaves was 42.86 a minimum number of leaves was observed in $\mathrm{T}_{0}$ (control) that is 32.13. At $90 \mathrm{DAS}$ the maximum 49.33 in $\mathrm{T}_{5}$-[NPK@ 50\% + 
Vermicompost @100\%], followed by $\mathrm{T}_{6^{-}}$ [NPK@100\% + Vermicompost @0\%] the number of leaves was 39.83 and minimum number of leaves was observed in $\mathrm{T}_{0}$ (control) (Muhammad and Khan, 2015).

\section{Number of branch per plant}

At 30 DAS, the Number of Branch per plant 22.43 in $\mathrm{T}_{8}$-[NPK@ $100 \%+$ Vermicompost@100], followed by $\mathrm{T}_{7^{-}}$ [NPK@100\% + Vermicompost@ 50\%] the Number of Brach per plant was 19.27 and Number of Branch per plant was observed in $\mathrm{T}_{0}$ (control) that is 14.77 .

At 60 DAS, the maximum 47.20 in $\mathrm{T}_{8-}$ [NPK@100\% + Vermicompost@100\%], followed by $\mathrm{T}_{7^{-}}$[NPK@ 100\%+ Vermicompost@ 50\%] the Number of Brach per plant was 44.77an minimum Number of Brach per plant was observed in $\mathrm{T}_{0}$ (control) that is 38.37 .

At 90 DAS the maximum 48.50 in $\mathrm{T}_{8}$-[NPK@ 100\% + Vermicompost@100\%], followed by $\mathrm{T}_{7^{-}}$[NPK @ 100\% + Vermicompost@ 50\%] the Number of Brach per plant was 45.60 and minimum Number of Brach per plant was observed in $\mathrm{T}_{0}$ (control) (Wagh et al., 2014).

\section{Number of fruit per plant}

At 90 DAS, the maximum 20.71in $\mathrm{T}_{4}$ [NPk@50\% + Vermicompost@50], followed by $\mathrm{T}_{3}$ - [NPK@100\%+Vermicompost@0\%] the number of leaves was 19.86 and minimum No of fruits was observed in $\mathrm{T}_{0}$ (control) that is 15.56 (Firoz, 2009).

\section{Yield (q ha $\left.{ }^{-1}\right)$}

At 90DAS, the maximum Fruit yield 199.21 in $\mathrm{T}_{5}$-[NPK@50\% + Vermicompost@100\%], followed by $\mathrm{T}_{4^{-}}$[NPK@ $50 \%+$ Vermicompost@ 50\%] the fruit yield was
166.04 and minimum grain yield was observed in $\mathrm{T}_{0}$ (control) that is $107.81\left(\mathrm{qha}^{-1}\right)$ (Wagh et al., 2014) (Table 1).

\section{Soil pH}

The data showed that there was significant difference between treatments.

The significantly of maximum $\mathrm{pH}\left(\mathrm{dSm}^{-1}\right)$ of soil (7.40) was observed in $\mathrm{T}_{5}$ (N P and K @ 50\% + Vermicompost @ 100\%) followed by (7.29) with treatment $\mathrm{T}_{2}$ (N P and K @ 0\% + Vermicompost@100\%) and the minimum (7.10) was recorded with $\mathrm{T}_{0}(\mathrm{~N} \mathrm{P}$ and $\mathrm{K} @$ 0\%+Vermicompost@0\%).

Similar finding has been recorded by followed by Salvi et al., (2015) (Table 2).

\section{$\mathrm{EC}\left(\mathrm{dSm}^{-1}\right.$ at $\left.25^{\circ} \mathrm{C}\right)$}

The data showed that there was significant difference between treatments. The significantly of maximum EC $\left(\mathrm{dSm}^{-1}\right)$ of soil (0.52) was observed in $\mathrm{T}_{5}$ (N P and K @ 50\% + Vermicompost @ 100\%) followed by (0.48) with treatment $\mathrm{T}_{7}$ (N P and K@100\% + Vermicompost @ 50\%) and the minimum (0.28) was recorded with $\mathrm{T}_{0}(\mathrm{~N} \mathrm{P}$ and $\mathrm{K}$ @ 0\% + Vermicompost @ 0\%) Similler finding reported (Salvi et al., 2015).

\section{$\%$ Organic carbon}

The data showed that there was significant difference between treatments. The significantly of maximum soil organic carbon $\left(0.84 \mathrm{~g} \mathrm{~cm}^{-3}\right)$ was observed in $\mathrm{T}_{5}(\mathrm{~N} \mathrm{P}$ and $\mathrm{K}$ @ 50\% + Vermicompost @ 100\%) followed by $\left(0.75 \mathrm{~g} \mathrm{~cm}^{-3}\right)$ with treatment $\mathrm{T}_{7}(\mathrm{~N} \mathrm{P}$ and $\mathrm{K}$ @100\% + Vermicompost @ 50\%) and the minimum $\left(0.60 \mathrm{~g} \mathrm{~cm}^{-3}\right)$ was recorded with $\mathrm{T}_{0}$ (N P and K@0\% + Vermicompost@0\%). Similar results have also been recorded by Salvi et al., (2015). 
Fig.1 Estimation of EC, pH, \%O.C $\mathrm{N}_{2} \mathrm{O}, \mathrm{P}_{2} \mathrm{O}_{5}, \mathrm{~K}_{2} \mathrm{O}$

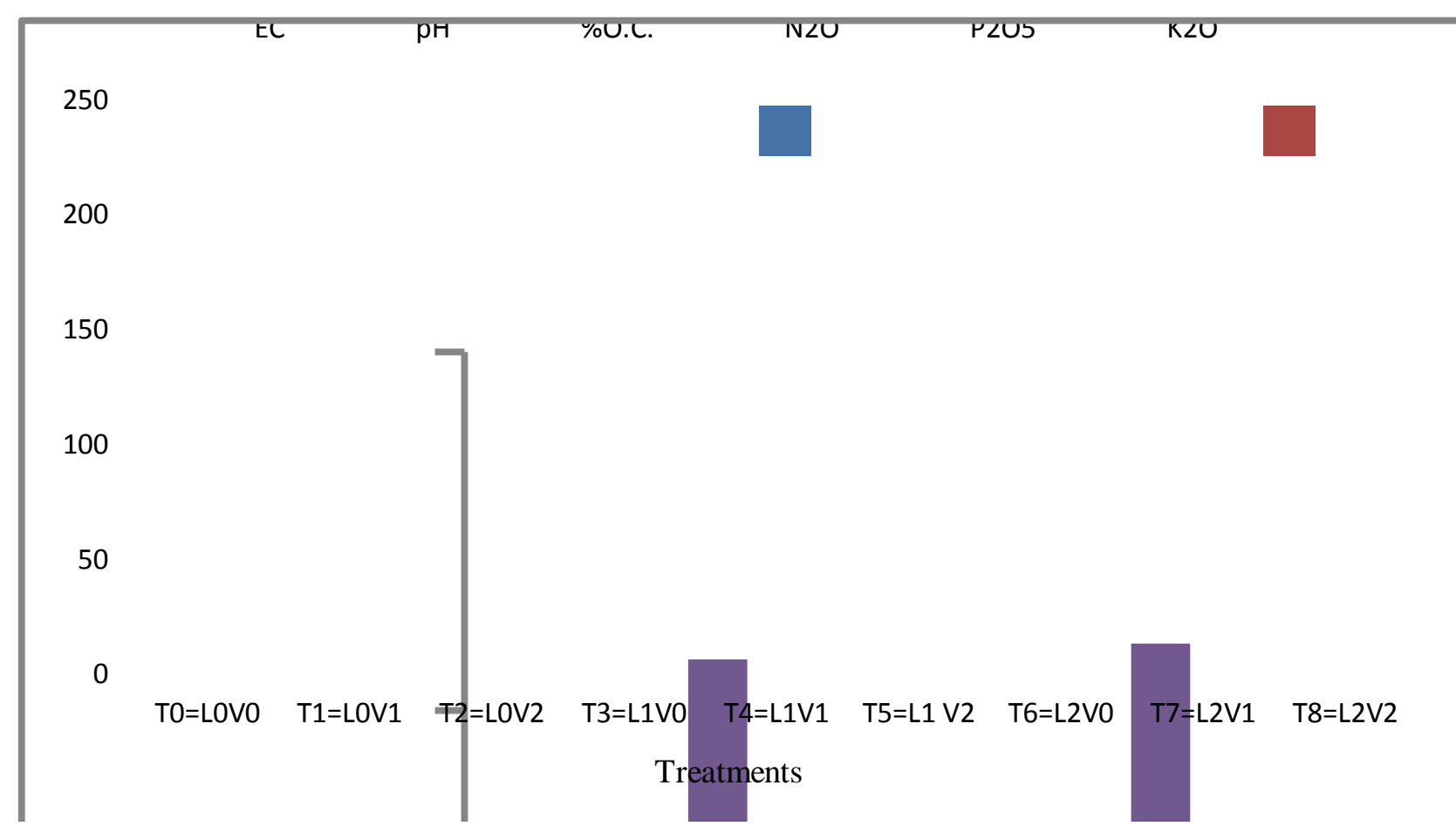

Fig.2 Estimation of partical density, bulk density, \%pore space

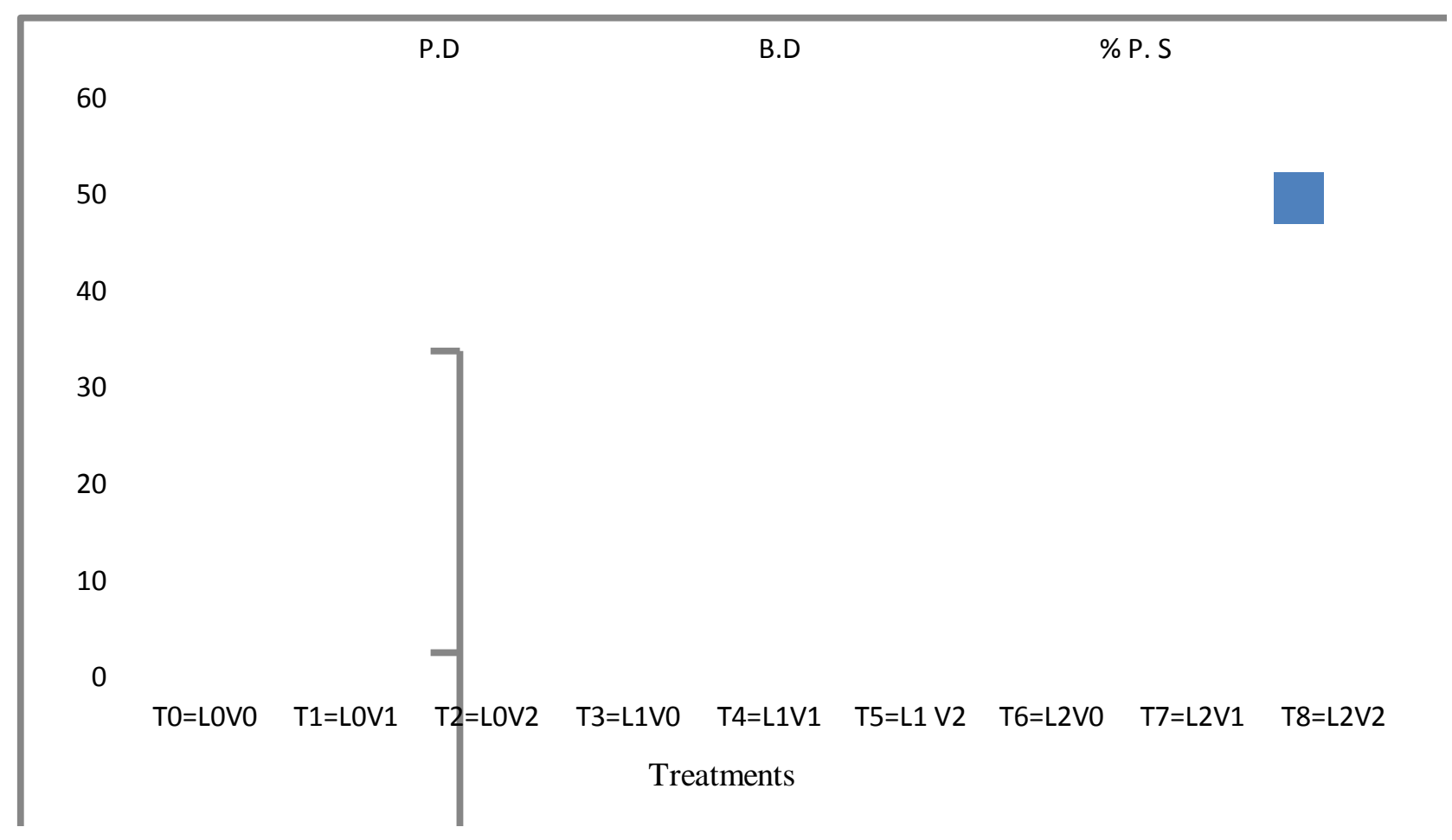


Fig.3 (1) Plant height (cm); (2) No. of Leaves plant ${ }^{-1}$; (3) No. of Branch per plant ${ }^{-1}$; (4) No. of Fruits plant $^{-1}$; (5) Fruits yield $\left(\mathrm{q} \mathrm{ha} \mathrm{h}^{-1}\right)$

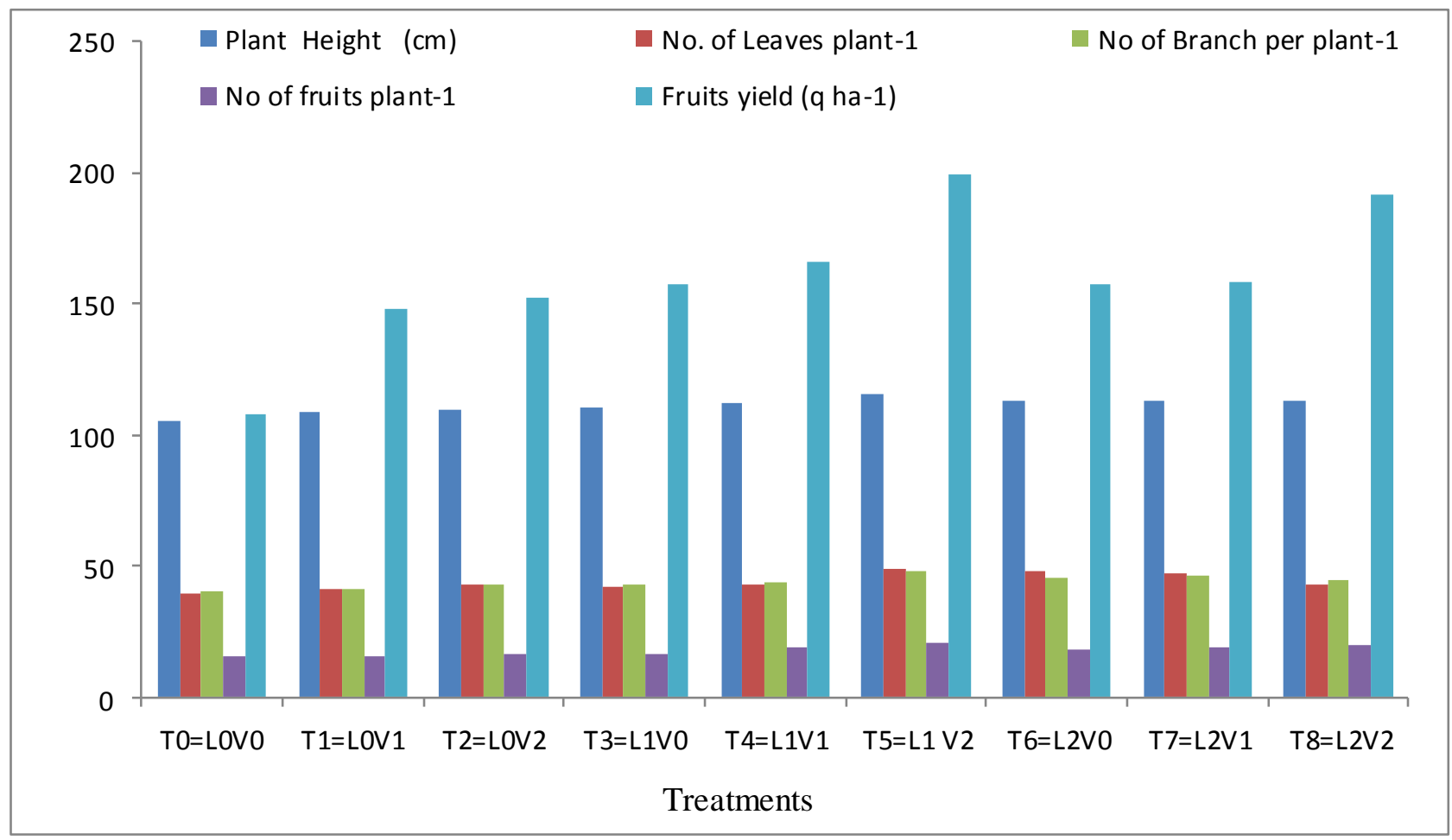

Table.1 Effect different levels of NPK and vermicompost on attribute and yield of okra (90 DAS)

\begin{tabular}{|c|c|c|c|c|c|c|}
\hline TREATMENT & $\begin{array}{c}\text { Plant } \\
\text { Height } \\
\text { (cm) }\end{array}$ & $\begin{array}{c}\text { No. of } \\
\text { Leaves } \\
\text { plant }^{-1}\end{array}$ & $\begin{array}{c}\text { No of } \\
\text { Branch } \\
\text { per plant }^{-1}\end{array}$ & $\begin{array}{l}\text { No of } \\
\text { fruits } \\
\text { plant }^{-1}\end{array}$ & $\begin{array}{c}\text { Fruits } \\
\text { yield (q } \\
\left.\text { ha }^{-1}\right)\end{array}$ & $\begin{array}{c}\text { Cost } \\
\text { Benefit } \\
\text { ratio } \\
\text { (C:B) }\end{array}$ \\
\hline $\mathbf{T}_{0}=\mathrm{L}_{0} \mathrm{~V}_{0}$ & 105.71 & 39.83 & 40.63 & 15.56 & 107.81 & $1: 1.71$ \\
\hline$T_{1}=L_{0} V_{1}$ & 108.43 & 41.66 & 41.60 & 15.98 & 148.57 & $1: 1.80$ \\
\hline$T_{2}=L_{0} V_{2}$ & 109.39 & 43.33 & 42.60 & 16.21 & 152.83 & $1: 0.38$ \\
\hline$T_{3}=L_{1} V_{0}$ & 110.73 & 42.06 & 43.43 & 16.89 & 157.91 & $1: 8.54$ \\
\hline $\mathbf{T}_{4}=\mathrm{L}_{1} \mathrm{~V}_{1}$ & 111.93 & 43.43 & 43.97 & 19.49 & 166.04 & $1: 1.45$ \\
\hline$T_{5}=L_{1} V_{2}$ & 115.59 & 49.33 & 48.50 & 20.71 & 199.21 & $1: 8.55$ \\
\hline $\mathbf{T}_{6}=\mathrm{L}_{2} \mathbf{V}_{0}$ & 113.20 & 48.16 & 45.60 & 18.23 & 157.81 & $1: 1.53$ \\
\hline $\mathbf{T}_{7}=\mathbf{L}_{2} \mathbf{V}_{1}$ & 112.87 & 46.91 & 46.50 & 19.21 & 158.57 & $1: 1.60$ \\
\hline $\mathbf{T}_{8}=\mathbf{L}_{2} \mathbf{V}_{2}$ & 113.53 & 42.94 & 44.37 & 19.89 & 191.82 & $1: 2.48$ \\
\hline Mean & 111.53 & 44.18 & 44.13 & 18.01 & 160.06 & \\
\hline F-test & $\mathrm{S}$ & $\mathbf{S}$ & $\mathbf{S}$ & $\mathbf{S}$ & $\mathbf{S}$ & \\
\hline S. $\operatorname{Em}( \pm)$ & 0.016 & 0.510 & 0.236 & 0.318 & 0.759 & \\
\hline C. D. at $5 \%$ & 0.033 & 1.881 & 0.501 & 0.674 & 1.603 & \\
\hline
\end{tabular}


Table.2 Effect of different levels of NPK and Vermicompost on Physico-Chemical properties of Soil

\begin{tabular}{|c|c|c|c|c|c|c|c|c|c|}
\hline TREATMENT & EC & pH & O.C. & P.D & B.D & P. $\mathbf{S}$ & $\mathbf{N}_{\mathbf{2}} \mathbf{O}$ & $\mathbf{P}_{\mathbf{2}} \mathbf{O}_{\mathbf{5}}$ & $\mathbf{K}_{\mathbf{2}} \mathbf{O}$ \\
\hline $\mathrm{T}_{0}=\mathrm{L}_{0} \mathrm{~V}_{0}$ & 0.28 & 7.1 & 0.6 & 2.43 & 1.16 & 40.06 & 207.17 & 16 & 115.98 \\
\hline $\mathrm{T}_{1}=\mathrm{L}_{0} \mathrm{~V}_{1}$ & 0.4 & 7.14 & 0.66 & 2.5 & 1.37 & 42.31 & 209.48 & 16.61 & 123.05 \\
\hline $\mathrm{T}_{2}=\mathrm{L}_{0} \mathrm{~V}_{2}$ & 0.44 & 7.29 & 0.73 & 2.64 & 1.43 & 46.31 & 211.49 & 17.51 & 127.83 \\
\hline $\mathrm{T}_{3}=\mathrm{L}_{1} \mathrm{~V}_{0}$ & 0.46 & 7.11 & 68 & 2.62 & 1.33 & 47.88 & 213.48 & 19 & 131.11 \\
\hline $\mathrm{T}_{4}=\mathrm{L}_{1} \mathrm{~V}_{1}$ & 0.43 & 7.26 & 0.66 & 2.57 & 1.37 & 47.96 & 217.19 & 19.59 & 127.57 \\
\hline $\mathrm{T}_{5}=\mathrm{L}_{1} \mathrm{~V}_{2}$ & 0.52 & 7.40 & 0.84 & 2.73 & 1.46 & 53.06 & 229.48 & 24.03 & 147.87 \\
\hline $\mathrm{T}_{6}=\mathrm{L}_{2} \mathrm{~V}_{0}$ & 0.5 & 7.13 & 0.69 & 2.41 & 1.39 & 47.02 & 222.17 & 21.1 & 139.95 \\
\hline $\mathrm{T}_{7}=\mathrm{L}_{2} \mathrm{~V}_{1}$ & 0.48 & 7.16 & 0.75 & 2.57 & 1.33 & 48.83 & 225.2 & 22.87 & 144.27 \\
\hline $\mathrm{T}_{8}=\mathrm{L}_{2} \mathrm{~V}_{2}$ & 0.42 & 7.11 & 0.74 & 2.63 & 1.34 & 47.75 & 219.22 & 21.21 & 134.57 \\
\hline Mean & $\mathbf{0 . 4 3 6}$ & $\mathbf{7 . 1 8 8}$ & $\mathbf{8 . 1 8 5}$ & $\mathbf{2 . 5 6 6}$ & $\mathbf{1 6 . 0 9 3}$ & $\mathbf{4 6 . 7 9 7}$ & $\mathbf{2 1 7 . 2 0 8}$ & $\mathbf{1 9 . 7 6 8}$ & $\mathbf{1 3 2 . 4 6 6}$ \\
\hline F- test & $\mathbf{N S}$ & $\mathbf{N S}$ & $\mathbf{N S}$ & $\mathbf{N S}$ & $\mathbf{S}$ & $\mathbf{S}$ & $\mathbf{S}$ & $\mathbf{S}$ & $\mathbf{S}$ \\
\hline S. Em $\mathbf{\text { Em }}$ & 0.029 & 0.013 & 0.015 & 0.078 & 0.036 & 0.468 & 1.588 & 0.228 & 2.240 \\
\hline C. D. at 5\% & 0.062 & 0.028 & 0.032 & 0.166 & 0.076 & 0.992 & 3.367 & 0.483 & 4.749 \\
\hline
\end{tabular}

Particle density $\left(\mathrm{M} \mathrm{gm}^{-3}\right)$ of soil

The data showed that there was significant difference between treatments. The Nonsignificantly of maximum Soil Particle density $\left(2.73 \mathrm{~g} \mathrm{~cm}^{-3}\right)$ was observed in $\mathrm{T}_{5}(\mathrm{~N} \mathrm{P}$ and K@50\% + Vermicompost@100\%) followed by $\left(2.64 \mathrm{~g} \mathrm{~cm}^{-3}\right)$ with treatment $\mathrm{T}_{2}(\mathrm{~N}$ P and K@0\%+Vermicompost@ 100\%) and the minimum $\left(2.43 \mathrm{~g} \mathrm{~cm}^{-3}\right)$ was recorded with $\mathrm{T}_{0}$ (N P and K@ 0\% + Vermicompost@0\%). Similar results have also been recorded by Attigah et al., (2013).

\section{Bulk density $\left(\mathrm{M} \mathrm{gm}^{-3}\right)$ of soil}

The data showed that there was significant difference between treatments. The significantly of maximum Soil Bulk density $\left(1.46 \mathrm{~g} \mathrm{~cm}^{-3}\right)$ was observed in $\mathrm{T}_{5}(\mathrm{~N} \mathrm{P}$ and $\mathrm{K}$ @ 50\% + Vermicompost @ 100\%) followed by $\left(1.43 \mathrm{~g} \mathrm{~cm}^{-3}\right.$ ) with treatment $\mathrm{T}_{2}$ ( $\mathrm{N} \mathrm{P}$ and $\mathrm{K}$ @ 0\%+Vermicompost @ 100\%) and the minimum $\left(1.16 \mathrm{~g} \mathrm{~cm}^{-3}\right)$ was recorded with $\mathrm{T}_{0}$ (N P and K @0\%+Vermicompost@0\%).

Similar results have also been recorded by Attigah et al., (2013).
$\%$ pore space of soil

The data showed that there was significant difference between treatments. The significantly of maximum Soil Pore space (53.06\%) was observed in $\mathrm{T}_{5}$ (N P and K @ 50\% + Vermicompost @ 100\%) followed by (48.83\%) with treatment $\mathrm{T}_{7}$ (N P and $\mathrm{K} @$ 100\% + Vermicompost@ 50\%) and the minimum (40.06\%) was recorded with $\mathrm{T}_{0}$ (control). Similar results have also been recorded by Attigah et al., (2013) (Fig. 2).

\section{Available nitrogen $\left(\mathrm{kg} \mathrm{ha}^{-1}\right)$}

The data showed that there was significant difference between treatments. The significantly of maximum Available Nitrogen $\left(229.48 \mathrm{~kg} \mathrm{ha}^{-1}\right)$ was observed in $\mathrm{T}_{5}(\mathrm{~N} \mathrm{P}$ and $\mathrm{K} @ 50 \%+$ Vermicompost @ 100\%) followed by $\left(225.20 \mathrm{~kg} \mathrm{ha}^{-1}\right)$ with treatment $\mathrm{T}_{7}$ (N P and K @ 100\% + Vermicompost @ $50 \%)$ and the minimum $\left(207.17 \mathrm{~kg} \mathrm{ha}^{-1}\right)$ was recorded with $\mathrm{T}_{0}$ (control).

Similar results have also been recorded by Salviet et al., (2015). 


\section{Available phosphorus $\left(\mathrm{kg} \mathrm{ha}^{-1}\right)$}

The data showed that there was significant difference between treatments. The significantly of maximum Available phosphorous (24.03 $\mathrm{kg} \mathrm{ha}^{-1}$ ) was observed in $\mathrm{T}_{5}$ (N P and K@ $@ 50 \%+$ Vermicompost @ $100 \%)$ followed by $\left(22.87 \mathrm{~kg} \mathrm{ha}^{-1}\right)$ with treatment $\mathrm{T}_{7} \quad(\mathrm{~N} \quad \mathrm{P}$ and $\mathrm{K} @ 100 \%+$ Vermicompost @ 50\%) and the minimum (16.00 $\mathrm{kg} \mathrm{ha}^{-1}$ ) was recorded with $\mathrm{T}_{0}$ (control). Similar results have also been recorded by Salvi et al., (2015).

\section{Available potassium (kg ha $\left.{ }^{-1}\right)$}

The data showed that there was significant difference between treatments. The significantly of maximum Available potassium (147.87 $\left.\mathrm{kg} \mathrm{ha}^{-1}\right)$ was observed in $\mathrm{T}_{5}$ (N P and K@ 50\% + Vermicompost @ $100 \%)$ followed by (144.27 $\left.\mathrm{kg} \mathrm{ha}^{-1}\right)$ with treatment $\mathrm{T}_{7}(\mathrm{~N} \mathrm{P}$ and $\mathrm{K} @ 100 \%+$ Vermicompost@ 50\%) and the minimum (115.98 $\mathrm{kg} \mathrm{ha}^{-1}$ ) was recorded with $\mathrm{T}_{0}$ (control). Similar results have also been recorded by Salvi et al., (2015).

It is concluded from trail that the various levels of nutrients used from different sources in the experiment. The combined application of NPK fertilizers @ $\mathrm{N}_{20} \mathrm{P}_{50} \mathrm{~K}_{30} \mathrm{~kg} \mathrm{ha}^{-1}+$ Vermicompost@ $5 \mathrm{t} \mathrm{ha}^{-1}$ was found to be the best in the plant height $(115.69 \mathrm{~cm})$, no. of leaves per plant (49.33), Fruits yield (199.21 $\mathrm{q} \mathrm{ha}^{-1}$ ) (Fig. 3). The physical and chemical properties of soil such as bulk density (1.46 $\left.\mathrm{Mgm}^{-3}\right)$, particle density $\left(2.73 \mathrm{Mgm}^{-3}\right)$, pore space $(48.83 \%)$ and EC $\left(0.52 \mathrm{dSm}^{-1}\right), \mathrm{pH}$ (7.40), \% organic carbon (0.84), available $\mathrm{N}$ (229.48 $\left.\mathrm{kg} \mathrm{ha}^{-1}\right), \mathrm{P}\left(24.03 \mathrm{~kg} \mathrm{ha}^{-1}\right), \mathrm{K}(147.87$ $\left.\mathrm{kg} \mathrm{ha}{ }^{-1}\right)$, was found to be the best in the treatment combination of $\mathrm{T}_{5}$ (Figs. 1-3). The maximum net return $\left(37,154.6 ₹ / \mathrm{ha}^{-1}\right)$ was achieved in the treatment combination of $\mathrm{T}_{5}$. Since the result is based on one season experiment. Therefore, further trial is needed to substantiate the results.

\section{References}

Anonymous (2014). A report by Indian Horticulture Database.

Asgedom, H. and M. Becker. (2001). Effect of seed priming with nutrient solutions on germination, seedling growth and weed competitiveness of cereals in Eritrea. In: Proc. Deutscher Tropentag 2001, Univ. Bonn and ATSAF, Margraf Publishers Press, Weickersheim. p. 282.

Attigah, Antoinette Sena. Emmanuel KwasiAsiedu, Kofi Agyarko and Harrison Kwame Dapaah (2013) Growth and yield of okra (Abelmoschus esculentus (L.) as affected by organic and inorganic fertilizers. Journal of Agricultural and Biological Science.vol.8 no.12, December (2013).

Black, C.A. (1965) Methods of soil analysis vol.2, Am.Soc, Agron.madison, Wisconsin, U.S.A.

Bray R.H. and Kurtz, L.T. (1945). Determination of total organic and available form of phosphorus in soil. Soil Sci., 59: 39-44

Bouyoucos, G.J. (1927) the hydrometer as a new method for the mechanical analysis of soils. soil.scence 23: pp 343-353.

Bose, T.K., Som, M.G. and Kabir, J. (1985). Vegetable crops. Naya Prakash, Calcutta. pp. 711-724.

Chien, S. H., L. I. Prochnow, S. Tu and C. S. Synder (2011). The agronomic and environmental aspects of phosphate fertilizers varying in source and solubility: an update review. Nutrient Cycl Agroecosyst 89:229-255

Firoz, Z. A. (2009)Impect of Nitrogen and Phosphorus on the growth and yield of okra [Abelmoschus esculentus(L.)] in hill slope condition. Bangladesh J. Agril. Res. 34(4) : 713-722, December 2009.

Gayathri and Syam Sundar Reddy (2013) Effect of integrated nutrient management growth and yield of okra [Abelmoschus esculentus $(\mathrm{L})$.] cv. ArkaAnamika. Vegetable Science (2013) 40 (2) : 246-248 
Halkatti, S.V., Doddamani and Nagnur, S.V. (1997). Importance of organic manure in agriculture. Farmers and Parliament, 33(2): 17-18.

Jackson, M.L. (1973). Soil chemical analysis Prentice-Hall of India Pvt. Ltd., New Delhi. pp. 134-182

Khalil, I. A. (2006). Crops and Cropping patterns In Pakistan: Crop Nutrition. 6th Chapter. HEC Publisher, Islamabad. pp. 64-65.

Kuppusamya, M. R. SankarandV. Sundaram (2013) Effect of organic sources of nitrogen on growth and yield of bhendi [Abelmoschus esculentus (L.)] the assianjouranal of horticulture Volume 8 | Issue 1 | June, 2013 | 154-157.

Mahapatra, P. B. Mal, S. Mohanty and H. N. Mishra (2013) Growth and yield parameters of okra (Abelmoschus esculentus) influenced by Diazotrophs and chemical fertilizers Journal of Crop and Weed, 9(2):109-11.

Muhmood, Atif Abdul Majeed, AbidNiaz, S. Javid,SyedShahid Hussain Shah and Asrar Hussain Shah (2015) Nutrients Uptake and the Yield of Okra in Response to Bioslurry and Inorganic N Fertilizers. International Journal of Plant and Soil Science 7(5): 297305 ,

Olsen, S.R. Cole, C.V. Watnahe, F. S. and Daen, L.A. (1954) Estimate of available phosphorus in soil by extraction with sodium bicarbonate U.S. Deptt.Agri.ciric.939

Sadat, M. S. I. (2000). Studies on the effects of different levels of nitrogen, phosphorous and potassium on the growth yield and seed production of okra (Abelmoschus esculentus L.). M S. Thesis, Dept. of Horticulture, Bangladesh Agril. Univ., Mymensingh, Bangladesh.
Salvi,V.G. MinalShinde, Bhureand M.H. Khanvilkar (2015) Effect of integrated nutrient management on soil fertility and yield of okra in coastal region of Maharashtra An Asian Journal of Soil ScienceVolume10| Issue 2 | 201-209.

Sajid, M. M., A. Khan, A. Rab, S. N. M. Shah, M. Arif, I. Jan, Z. Hussain and M. Mukhtiar (2012). Impect of nitrogen and phosphorus on seed yield and components of okra cultivars. The Journal of Animal and Plant Sciences, 22(3): 2012, Page: 704-707.

Somkumar, R.G., Mahakal, K.G. and Kale, P.B. (1997). Effect of different levels of nitrogen on growth and yield of okra varieties. $P K V$ Res. J., 21: 22-24.

Subbaih, B.V., and Asija, C.L. (1956) A rapid procedure for the estimation of available nitrogen in soil. Current Sciences; 25:259260.

Toth, S.J. and A.L. Prince (1949) Estimate of cation exchange capacity and exchangeable $\mathrm{Ca}, \mathrm{K}, \mathrm{Na}$, content of soil by flame photometer technique soil science.67:439445.

Vennila, C. and Jayanthi, C. (2008). Response of okra to integrated nutrient management. $J$. Soils and Crop, 18 (1)36-40.

Wagh, S.S., Laharia, A.G. Iratakar and A.S. Gujare (2014) Effect of INM on nutrient uptake, yield and quality of okra [Abelmoschus esculents (L.)] An Asian Journal of Soil Science Volume 9 | Issue 1 | 21-24.

Wakley, A. and Black, I.A. (1947) Critical examination of rapid method for determining organic carbon in soils, effect of variance in digestion conditions and of inorganic soil constituents. Soil sci.632:251.

Wilcox, L.V. (1950) Electrical conductivity, Am. water work Assoc. J., 42: pp. 775-776.

\section{How to cite this article:}

Reena Lakra, Narendra Swaroop and Tarence Thomas. 2017. Effect of Different Levels of NPK and Vermicompost on Physico-Chemical Properties of Soil, Growth and Yield of Okra [Abelmoschus esculentus L.] var. Rohini. Int.J.Curr.Microbiol.App.Sci. 6(7): 1398-1406. doi: https://doi.org/10.20546/ijcmas.2017.607.167 